
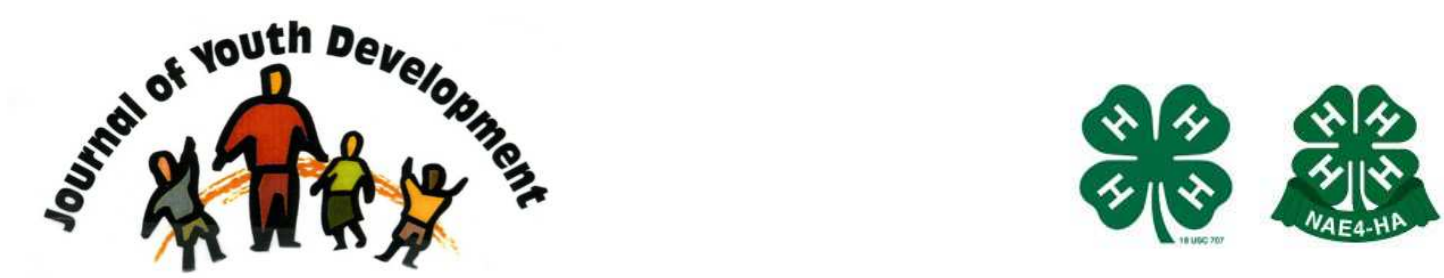

Bridging Research \& Practice

\title{
Addressing Hunger Issues Through Service Learning
}

\author{
Nancy Kershaw \\ Oregon State University Extension Service \\ Tillamook, OR \\ nancy.kershaw@oregonstate.edu \\ Joy Jones \\ Oregon State University Extension Service \\ Tillamook, OR \\ joy.jones@oregonstate.edu \\ Sally Bowman \\ Oregon State University Extension Service \\ Corvallis, OR \\ bowmans@oregonstate.edu \\ Holly Berry \\ Oregon State University Extension Service \\ Salem, OR \\ holly.berry@oregonstate.edu
}




\title{
JOURNAL OF YOUTH DEVELOPMENT \\ bridging research and practice
}

\section{Addressing Hunger Issues Through Service Learning}

\author{
Nancy Kershaw, Joy Jones, Sally Bowman and Holly Berry \\ Oregon State University
}

\begin{abstract}
The U.S. Government has set a goal of reducing the prevalence of food insecurity to $6 \%$ or less by 2010 . To achieve this goal, education and action are necessary. Youth in Oregon were introduced to the issue through the role playing simulation, Are You Hungry Tonight?

The simulation was utilized with youth, adult volunteers, and youth development staff. Participants indicated increased understanding of people with limited resources, including:

- Financial pressures, emotional stresses and frustrations they face

- Difficulty of improving one's situation

- Difficult choices people make

- Positive and negative impacts of community organizations
\end{abstract}

Simulation participants developed an understanding of hunger issues and empathy for people experiencing food insecurity. Participants were subsequently challenged to complete service learning projects that would help provide additional food resources for their communities. Providing education through the simulation set the stage for youth to participate fully in service learning projects to help alleviate hunger.

\section{"Service-learning is education in action." - Senator John Glenn}

\section{Introduction}

The majority of households in the United States have an adequate supply of food to provide for active, healthy living. The United States Department of Agriculture defines this as being "food secure." Although the United States is one of the largest food producers in the world, there are still 11 percent (12.6 million) of households who are food insecure, which means that at some 
time during the year they had difficulty providing enough food for all members due to lack of resources. In 2005, 4.4 million US households had very low food security (previously defined as hunger). In these households, some members reduced their normal eating patterns because of a lack of money and resources (Nord, Andrews, \& Carlson, 2006).

In 2003, Oregon led the nation in food insecurity rates, even though it is one of the largest agricultural producers. As a result, hunger was identified as an issue that needed to be addressed through all Cooperative Extension program areas in Oregon, including both youth and adult audiences. An important goal for educators is to challenge existing knowledge and attitudes about poverty and hunger by decreasing stereotypes and encouraging critical thought both inside and outside the classroom (Bowman, Bairstow, \& Edwards, 2003; Ruben, 1999).

4- $\mathrm{H}$ is the positive youth development of the Cooperative Extension Service. Since one of the goals of 4-H is to involve youth in community service and service learning projects, it seemed natural to link these projects with hunger and poverty issues. Service-learning is a teaching method that enriches learning by engaging students in meaningful service to their schools and communities. Young people apply academic skills to solving real-world issues, linking established learning objectives with genuine needs. They lead the process, with adults as partners, applying critical thinking and problem-solving skills to concerns such as hunger, pollution, and diversity (National Youth Leadership Council, 2007).

Studies have demonstrated that students who engage in high quality service-learning programs showed an increase in the degree to which they felt aware of community needs, believed that they can make a difference and were committed to service now and in later life (Berkas, 1997; Melchior, 1999). More than $80 \%$ of participants in high-quality service learning programs felt that they had made a positive contribution to the community (Billig, \& Conrad, 1997; Melchior, 1999; Scales, \& Blyth, 1997).

Simulations are role play activities that can help move participants into high-quality service learning projects, characterized by providing structured time for youth to reflect on their service by examining themselves, their society, and their future. Simulations are one form of experiential learning used in educational and community settings that engage an audience in active learning where participants learn from each other, not just from the "expert" on the stage. According to Jessup (2001, p. 103), "Simulations are also more effective than conventional teaching methods at emphasizing abstract concepts over factual information, engendering empathy, and serving as a reference for ongoing discussions regarding social inequality."

\section{Program Description}

This program was designed to engage 4-H audiences, youth and adults, in addressing the issue of hunger. The goal was to move participants from merely understanding the issue to participating fully in efforts to alleviate hunger.

To introduce the issue 4-H teens, leaders and staff participated in "Are You Hungry Tonight," a simulation activity designed for adults or youth (Berry, \& Bowman, 2006). The purpose of the simulation is to bring the complex issue of hunger and food insecurity into the realm of personal experience, helping participants develop greater understanding of the many compounding 
factors that can make it difficult to achieve economic self-sufficiency and, therefore, food security.

The educational objectives of the simulation were to better understand:

- The high rates of hunger and insecurity that exist in many communities;

- How difficult it often is for financially stressed people to improve their situations;

- Hunger as a public policy issue;

- Painful choices people make when stretching limited resources;

- How community organizations can help people work toward financial self-sufficiency.

The hunger simulation takes place in Anytown, Oregon, which depends on "The Company" as its primary employer. When The Company closes its Anytown plant, participants must seek out local resources in order to pay their bills and feed themselves and their families. During this simulation, which covers one year in four "15-minute months," participants assume roles of residents of Anytown as family members or agency staff members. Profiles for each role provide direction to the participant while providing opportunities for each participant to make decisions, which reveal how life events and personal choices can lead to food insecurity. Following the simulation, participants discuss their feelings and experiences.

\section{Program Evaluation}

Sixty-eight program participants in five different sessions completed a human subjects approved evaluation of their experience with the hunger simulation. The retrospective pre-test questionnaire asked them about their understanding of various issues before and after participation in the simulation on a scale of 1 (none) to 5 (very good). The retrospective pretest method (Pratt, McGuigan, \& Katzev, 2001) was appropriate for this evaluation because the retrospective pretest is quick, flexible, and does not produce an initial overestimation of knowledge and skills compared to a traditional pretest. The data was analyzed using SPSS.

Mean ratings on all five learning objectives before and after the simulation revealed statistically significant changes in levels of understanding. The ratings by participants of their understanding of these learning objectives before and after the simulation were:

\begin{tabular}{|l|l|l|l|}
\hline Question & Mean Before & Mean After & Significance \\
\hline $\begin{array}{l}\text { Financial pressures faced by the } \\
\text { unemployed }\end{array}$ & 3.02 & 4.08 & $\mathrm{p}<.001$ \\
\hline Difficulties improving one's situation & 3.02 & 4.11 & $\mathrm{p}<.001$ \\
\hline $\begin{array}{l}\text { Difficult choices people need to make each } \\
\text { month when stretching limited resources }\end{array}$ & 3.08 & 4.15 & $\mathrm{p}<.001$ \\
\hline $\begin{array}{l}\text { Emotional stresses and frustrations faced } \\
\text { by having limited resources }\end{array}$ & 3.20 & 3.97 & $\mathrm{p}<.001$ \\
\hline $\begin{array}{l}\text { Positive and negative impacts of } \\
\text { community organizations in the success or } \\
\text { failure of someone on a limited income }\end{array}$ & 2.73 & 3.89 & $\mathrm{p}<.001$ \\
\hline
\end{tabular}


Comments from youth who participated in the simulation include:

- It was fun because we had to feel like others in a similar situation. I think other kids should be involved in other workshops like these.

- It helps people know what they would go through when they get older, the responsibilities they are going to have.

- It was fun and kind of aggravating when I didn't get food stamps and stuff, but it was educational and I learned a lot.

- It did a good job of explaining how bad it sucks to be poor.

- I had never thought much about this since I have never been in a similar situation. It really opened my eyes to the troubles our communities have.

- Through the simulation you were able to act as if you were the one in trouble and through that I learned how frustrating and scary it could be.

When youth were asked what they might do as a result of participating in the simulation, responses included:

- Would try to donate more money and time to help with hunger.

- Helping out at places that help people.

- I have helped with local food drives and will help more with those as well as similar programs.

- Mention it to clubs to ensure community service activities that help low-income families.

- I know that lots of teens want to be more active in their communities. They would donate food or raise money for families.

- We need to better inform the public about what resources are available to them if they are in trouble.

- Speak to organizations about getting food donated to the food bank.

After participation in the simulation activity, $4-\mathrm{H}$ audiences were challenged to take their experience and apply it through hunger related service learning projects. This approach was used with 4- $\mathrm{H}$ teens at statewide Ambassador training, through teen retreats and forums for $4-\mathrm{H}$ youth and adult audiences throughout the state of Oregon.

Service learning projects included: volunteering at local food banks; sorting and repackaging food; coordinating food drives; conducting silent auctions to raise money for food; and participating in other activities that benefited low income families. Three 4-H Ambassadors from one county helped lead other county teens and the 4-H Leader's Association to focus on hunger and assistance to low income families as their county-wide community service focus.

As a result of participation in the hunger simulation and complementary service learning projects, staff observed increases in 4-H members' understanding and empathy of the issues faced by low income families. This resulted in increased enthusiasm of 4-H members for participating in community service projects. 


\section{Summary}

The U.S. Government has set a goal of reducing the prevalence of food insecurity from $12 \%$ as measured in 1995 - to $6 \%$ or less by 2010 (Nord, Andrews, \& Carlson, 2004). Hunger in the U.S., however, rose by $43 \%$ from 1999 to 2004 . This indicates that continued involvement in education about food insecurity issues is important for all audiences, including youth.

Evaluations from the youth who participated in this program indicate an increase in their understanding of food security issues and their empathy towards those in need. As a result of the program, youth may be more motivated to participate in community service projects that help reduce hunger.

This project could be replicated within any youth organization that includes a service learning component. It is also applicable in school settings where service learning is encouraged. Youth organizations that would like to use the simulation "Are You Hungry Tonight?" may contact the Oregon State University Extension Service for a copy of the simulation.

\section{References}

Berkas, T. (February, 1997). Strategic Review of the W.K. Kellogg Foundation's ServiceLearning Projects, 1990-1996. Battle Creek, MI: W.K. Kellogg Foundation.

Berry, H., \& Bowman, S. (2006). Are You Hungry Tonight? An Education Simulation of Hunger in Our Communities. Oregon State University Extension Service EM \#8892.

Billig, S., \& Conrad, J. (1997). An Evaluation of the New Hampshire Service-Learning and Educational Reform Project. Denver, CO: RMC Research.

Bowman, S., Bairstow, R., \& Edwards, M. (2003). Teaching about poverty in the classroom and beyond. Journal of Teaching in Marriage and Family, 3, 23-46.

Jessup, M.M. (2001). Sociopoly: Life on the boardwalk. Teaching Sociology, 29, 102-109.

Melchior, A. (1999). Summary Report: National Evaluation of Learn and Serve America. Waltham, MA: Center for Human Resources, Brandeis University.

National Youth Leadership Council. (2007). Discover Service Learning. Retrieved January 18, 2007, from http://www.nylc.org/discover.cfm?oid=3152

Nord, M., Andrews, M., \& Carlson, S. (2006). Household Food Security in the United States, 2005. Economic Research Report Number 29, U.S.D.A. (60 pp.).

Nord, M., Andrews, M., \& Carlson, S. (2004). Household Food Security in the United States, 2003. Food Assistance and Nutrition Research Report Number 42, U.S.D.A. (61 pp.).

Pratt, C.C., McGuigan, W.M., \& Katzev, A. (2001). Measuring program outcomes using retrospective pretest methodology. American Journal of Evaluation, 21, 341-349. 
Ruben, B. (1999). Simulations, games and experience-based learning: The quest for a new paradigm for teaching and learning.Simulation \& Gaming, 30, 498-505.

Scales, P., \& Blyth, D. (1997). Effects of service-learning on youth: What we know and what we need to know. Generator, Winter, 6-9.

(C) Copyright of Journal of Youth Development $~$ Bridging Research and Practice. Content may not be copied or emailed to multiple sites or posted to a listserv without copyright holder's express written permission. Contact Editor at: patricia.dawson@oregonstate.edu for details. However, users may print, download or email articles for individual use.

ISSN 2325-4009 (Print); ISSN 2325-4017 (Online) 